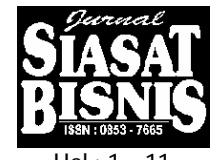

Hal.: $1-11$

\title{
PENTINGNYA KEPUASAN KONSUMEN DAN IMPLEMENTASI STRATEGI PEMASARANNYA*)
}

\author{
Asmai Ishak \\ Universitas Islam Indonesia
}

\begin{abstract}
Abstrak
Makin beragamnya produk di pasar, di satu sisi, akan menyenangkan konsumen, karena mereka memiliki banyak pilihan. Di mata produsen, di sisi lain, situasi tersebut menjadi sangat kompetitif. Artinya, pemasar atau perusahaan harus melakukan sejumlah upaya agar dapat merebut hati konsumen. Pada intinya upaya-upaya tersebut ditujukan untuk menjawab pertanyaan: bagaimana memuaskan konsumen sehingga mereka loyal kepada produk perusahaan. Pemahaman yang baik tentang pasar dan perilakunya, kiranya akan membuat upaya memuaskan konsumen menjadi relatif lebih mudah, karena, dari sini pemasar akan memiliki pengetahuan tentang minat beli konsumen terhadap suatu produk, proses pengambilan keputusannya, dan persepsi mereka terhadap produk perusahaan relatif jika dibandingkan dengan produk pesaing. Lain dari itu, jika para pemasar ingin konsumennya loyal terhadap produk perusahaan, mereka juga akan berupaya untuk memahami hal-hal lain yang mempengaruhi keputusan beli (ulang) konsumen. Selanjutnya semuanya itu akan menjadi dasar yang penting bagi penyusunan dan implementasi strategi pemasaran yang (kompetitif) memuaskan konsumen.
\end{abstract}

Kata kunci: kepuasan konsumen, pasar dan perilakunya, strategi pemuasan konsumen.

PENDAHULUAN

Perkembangan dunia bisnis di negara kita yang sudah berusia lebih dari 50 tahun ini nampak cukup pesat, khususnya dalam 25 tahun terakhir. Hal ini bisa kita lihat dengan semakin banyaknya pendirian perusahaan oleh para investor dan semakin beragamnya produk yang ditawarkan di pasar oleh para pelaku bisnis. Perkembangan ini cukup menyenangkan bagi kita semua, sebagai konsumen. Mengingat, dengan semakin beragamnya macam dan jenis produk yang ditawarkan memberikan peluang pada kita untuk membeli produk yang sesuai dengan keinginan kita. Tetapi perkembangan yang demikian itu, bisa dirasakan sebagai sebuah beban bagi para pelaku bisnis. Mereka tidak bisa lagi menjalankan bisnisnya tanpa perencanaan dan perhitungan yang matang, karena semakin bertambahnya pelaku bisnis dalam industri dapat berarti bertambahnya pesaing dan meningkatnya tingkat persaingan. Mereka harus mampu merebut hati pasar sasarannya untuk mencapai volume penjualan tertentu agar tetap bertahan atau mengembangkan usahanya dalam industri yang sudah dipilihnya. Dalam kondisi seperti ini kepuasan konsumen mempunyai

*) Jurnal Siasat Bisnis Edisi Th. I Vol. 3, Nopember 1996 
peranan yang cukup penting bagi perusahaan. Karena secanggih atau sebagus produk yang dihasilkan oleh perusahaan, jika konsumen tidak menyukainya, baik karena terlalu mahal atau terlalu rumit dalam penggunaannya, maka produk tersebut tidak ada artinya. Pada kenyataan lain mungkin saja konsumen enggan membeli merk tertentu karena produknya kurang berkualitas, tetapi mungkin mereka pernah dikecewakan dalam pelayanan pada saat atau pasca pembelian, atau karena merk tersebut hanya tersedia di tempat tertentu saja, atau mungkin saja karena sistem pembayaran yang sangat kaku. Fenomena ini menunjukkan bahwa untuk memuaskan konsumen bukan merupakan suatu permasalahan yang sederhana tetapi merupakan permasalahan yang komplek yang saling terkait. Oleh karena itu strategi memuaskan konsumen perlu dilakukan secara terencana dan terpadu. Tulisan ini mencoba akan mengurai dan membahas bagaimana sebaiknya menangani permasalahan kepuasan konsumen bagi perusahaan, yang beroperasi dalam industri yang kompetitif.

\section{PENGERTIAN PEMASARAN}

Seringkali terjadi salah pengertian dalam memahami arti pemasaran dalam sebuah perusahaan. Sering orang mengartikan pemasaran sebagai cara-cara yang dilakukan oleh perusahaan dalam menjual produknya. Yang lain mengartikan pemasaran sebagai usaha promosi atau cara perusahaan mempengaruhi konsumen agar membeli produknya. Arti pemasaran yang sebenarnya adalah lebih luas dari pengertian-pengertian itu. Seperti yang diungkapkan pakar pemasaran, Philip Kotler, pemasaran merupakan suatu proses social dan melalui proses tersebut, individu dan kelompok memperoleh apa yang mereka butuhkan dan inginkan dengan cara menciptakan dan mempertukarkan produk dan nilai dengan individu dan kelompok lain. Lebih kongkrit William J. Stanton, pakar yang lain, mengatakan bahwa pemasaran adalah suatu sistem keseluruhan dari kegiatan bisnis yang ditujukan untuk merencanakan, menentukan harga, mempromosikan, dan mendistribusikan barang dan jasa yang memuaskan kebutuhan baik kepada pembeli yang ada maupun pembeli potensial.

Dari kedua definisi di atas dapat kita simpulkan bahwa pemasaran tidak hanya terbatas pada kegiatan penjualan dan promosi saja, melainkan dimulai sejak merencanakan produk yang akan dipasarkan sampai pada cara pendistribusiannya. Namun demikian dalam kenyataannya, meskipun para pelaku bisnis sudah tahu dan paham tentang arti pemasaran, masih sering kita lihat mereka hanya menekankan pada beberapa aspek pemasaran saja dalam memasarkan produknya. Kenyataan ini tidak terlepas dari orientasi mereka dalam melakukan pemasaran. Dengan kata lain, hal ini sangat tergantung dari falsafah pemasaran (marketing philosophy) yang 
mereka gunakan. Untuk ini, Kotler mengajukan 5 macam orientasi/konsep pemasaran yang sering/dapat dilakukan perusahaan dalam melakukan upaya pemasaran yaitu konsep produksi, produk, penjualan, pemasaran, dan konsep pemasaran yang bersifat kemasyarakatan (social marketing concept).

Bagi perusahaan yang menggunakan konsep produksi dalam memasarkan produknya akan berpendapat bahwa para pelanggan akan menyukai produk-produk yang tersedia secara luas dan harganya murah. Konsekwensinya mereka akan berusaha untuk mencapai efisiensi produksi yang tinggi dan pendistribusian produk yang luas. Sementara bagi mereka yang menggunakan konsep produk beranggapan bahwa para konsumen akan menyukai produk-produk yang mempunyai kualitas, penampilan dan ciri-ciri yang baik. Oleh karenanya para pengelola perusahaan tersebut akan memfokuskan perhatiannya untuk dapat menghasilkan produk yang baik dan berkualitas dan secara kontinyu berusaha untuk meningkatkan kualitas dan penampilan produknya.

Pengusaha yang falsafah pemasarannya didasari oleh konsep penjualan berpandangan bahwa konsumen, jika dibiarkan sendiri, biasanya tidak akan membeli produk-produk yang ditawarkan. Untuk itu dia/mereka akan berusaha melakukan kegiatan penjualan yang agresif dan promosi yang gencar. Selanjutnya perusahaan yang menggunakan konsep pemasaran berpedoman bahwa kunci untuk mencapai tujuan-tujuan organisasi terdiri dari penentuan kebutuhan dan keinginan pasar sasaran dan penyerahan produk yang memuaskan secara lebih efektif dan lebih efisien dibandingkan para pesaingnya. Dengan kata lain tercapainya tujuan perusahaan sangat tergantung pada kemampuan mereka dalam memuaskan kebutuhan pasar sasarannya. Dengan demikian, perusahaan yang menggunakan konsep ini akan berusaha untuk mengetahui dan memonitor perubahan kebutuhan dan keinginan pasarnya untuk kemudian dijabarkan dalam bentuk produk yang didukung oleh sebuah pemasaran secara terpadu agar dapat memuaskan kebutuhan tersebut secara lebih baik dari pada para pesaingnya. Oleh karena itu, perusahaan yang menggunakan konsep ini berusaha memilih pasar tertentu yang diperkirakan dapat dilayani secara baik.

Konsep pemasaran yang terakhir adalah pemasaran yang bersifat kemasyarakatan. Konsep ini berpegang pada asumsi bahwa tugas organisasi adalah menentukan kebutuhan, keinginan, dan minat dari pasar sasaran serta memberikan kepuasan yang diharapkan dengan cara lebih efektif dan lebih efisien daripada pesaingnya sehingga dapat menjamin dan mendorong kesejahteraan konsumen dan masyarakat. Bagi perusahaan yang menggunakan konsep ini dalam melakukan pemasaran mereka akan memperhatikan keseimbangan tiga hal pokok yaitu pencapaian laba perusahaan, kepuasan dari kebutuhan dan keinginan, dan kepentingan masyarakat. 
Setelah mengetahui dasar falsafah pemasaran yang bisa dipergunakan oleh para pengusaha, maka muncul pertanyaan konsep manakah yang paling relevan untuk dijadikan pedoman dalam menjalankan usaha. Untuk menentukan konsep yang paling relevan tidak ditentukan oleh waktu dan zaman. Artinya, karena sekarang sudah zaman modern atau menjelang abad ke 21 maka konsep produksi atau penjualan tidak bisa dipergunakan. Yang menentukan relevan dan tidaknya penggunaan suatu konsep ditentukan oleh dua hal yaitu tingkat persaingan dan perubahan dalam suatu industri sangat rendah bahkan tidak ada maka tidak perlu perusahaan tersebut menggunakan konsep pemasaran dalam memasarkan produknya. Perusahaan yang berada dalam semacam itu cukup menggunakan konsep produksi. Karena konsumen tidak mempunyai alternatif pilihan produk lain di pasar. Jika kondisi tingkat persaingan dan perubahan dalam industri mulai meningkat maka konsep penjualan yang paling baik untuk dipergunakan. Namun demikian, kondisi industri seperti itu sangat sedikit kita jumpai dalam kenyataan. Dengan kaa lain, hampir sebagian besar para pelaku bisnis di era Indonesia Emas ini berada dalam industri yang tingkat persaingan dan perubahan yang tinggi. Oleh karena itu, tidak ada konsep lain yang bisa dipergunakan dalam memasarkan produknya selain konsep pemasaran, paling tidak.

\section{PENTINGNYA MEMAHAMI PASAR DAN PERILAKUNYA}

Seperti halnya pada pemasaran, orang sering memahami kata pasar dalam artian yang sangat sempit yaitu tempat bertemunya penjual dan pembeli. Sementara, kita tahu bahwa untuk melakukan transaksi penjualan di zaman higtech ini produsen tidak perlu bertemu secara fisik. Sehingga pengertian pasar seperti itu merupakan pemahaman yang sudah out of date.

Pasar, seperti yang dikemukakan oleh Kotler, merupakan sekumpulan lembaga yang mempunyai kebutuhan tertentu, tenaga beli (uang), dan keinginan untuk membelanjakan uangnya untuk memuaskan kebutuhannya. Jadi untuk dapat dikatakan sebagai pasar/konsumen, maka seorang individu atau sebuah lembaga harus mempunyai tiga unsur pokok tersebut. Jika mereka tidak mempunyai tiga unsur pokok tersebut maka masih dikatakan sebagai pasar/konsumen potensial. Oleh karena itu, dalam merealisir target penjualannya, perusahaan harus tahu unsur yang mana yang belum ada pada pasar sasarannya. Jika ternyata, pasar sasarannya kesulitan dalam hal tenaga beli, maka perusahaan sebaiknya menawarkan dengan sistem kredit. Jika kebutuhan terhadap produk perusahaan belum ada, maka perusahaan sebaiknya menawarkan dengan sistem kredit. Jika kebutuhan terhadap produk perusahaan belum ada, 
maka perusahaan harus mencari tahu pada saat kapan kebutuhan akan produk tersebut akan muncul, dan seterusnya. Usaha-usaha yang demikian ini dapat dikatakan sebagai usaha untuk memahami perilaku pasar/konsumennya.

Pada dasarnya, usaha memahami perilaku konsumen perusahaan yang merupakan kunci sukses pemasaran, tidak sesederhana memahami tiga unsur pokok di atas. Ketiga unsur tersebut merupakan suatu simplifikasi yang komplek dari konsumen. Karena untuk mengetahui kebutuhan dan kemauan untuk membelanjakan uang dari konsumen, perusahaan harus meneliti jumlah produk, kapan, dengan siapa, dan bagaimana produk tersebut dibeli dan dikonsumsi oleh konsumen. Selain itu perusahaan harus meneliti kegiatan konsumen yang tidak kasat mata seperti nilai, keinginan, persepsi, bagaimana mereka memproses informasi dan mengevaluasi alternatif produk, sampai pada bagaimana perasaan konsumen dalam memiliki proses pengambilan keputusan pembelian, konsumen dipengaruhi oleh banyak faktor baik yang berasal dari dalam dirinya seperti persepsi, motivasi, emosi, dan kepribadian, maupun yang berasal dari luar dirinya seperti, budaya, nilai, status social, kelompok, rumah tangga, dan kegiatan pemasaran. Faktor internal dan eksternal tersebut mempengaruhi sikap dan gaya hidup konsumen yang pada akhirnya mempengaruhi kebutuhan sehari-harinya.

Untuk mencapai pemahaman perilaku konsumen yang begitu komplek tersebut harus dilakukan melalui suatu penelitian pemasaran. Dengan penelitian tersebut perusahaan akan memperoleh gambaran tentang : sikap konsumen yang sebenarnya dari produk yang dipasarkan; bagaimana persepsi konsumen atas penampilan produk perusahaan baik dalam kaitannya dengan keinginan konsumen sendiri maupun dalam kaitannya dengan produk pesaing. Gambaran yang diperoleh dari penelitian tersebut, merupakan modal dasar perusahaan untuk menetapkan kebijakan pemasaran yang akan dijalankan seperti penempatan produk di pasar (product positioning), segmentasi pasar, pengembangan produk atau pasar baru, dan kebijakan bauran pemasaran serta kebijakan untuk go international.

\section{STRATEGI MEMUASKAN KEBUTUHAN KONSUMEN}

Seperti yang diuraikan di depan bahwa kunci keberhasilan perusahaan yang berada dalam industri yang tingkat persaingan dan perubahan lingkungan yang tinggi terletak pada seberapa jauh perusahaan tersebut dapat memuaskan kebutuhan dan keinginan pasar sasarannya. Konsumen yang puas terhadap merk/produk tertentu cenderung untuk membeli kembali merk/produk tersebut pada saat kebutuhan yang sama muncul di 
kemudian hari. Hal ini menunjukkan bahwa kepuasan konsumen merupakan faktor kunci bagi konsumen dalam melakukan pembelian ulang. Sementara pembelian ulang merupakan porsi terbesar dari volume penjualan perusahaan. Selanjutnya konsumen yang puas tersebut sangat dimungkinkan untuk mempengaruhi lingkungannya untuk mengkonsumsi merk/produk yang telah memuaskannya. Keadaan ini akan sangat membantu perusahaan dalam mempromosikan produknya. Dari kenyataan di atas nampak bahwa kepuasan konsumen merupakan faktor yang penting bagi kelangsungan hidup perusahaan untuk bertahan dalam persaingan.

Untuk dapat memuaskan konsumennya, perusahaan dapat memulai dari mencari tahu kebutuhan dan keinginan itu sendiri. Atau dengan kata lain perusahaan harus tahu motif konsumen dalam membeli suatu produk. Apakah konsumen membeli produk untuk memperoleh manfaat inti dari produk ataukah mereka membeli produk tersebut akan memperoleh tambahan manfaat dari produk yang dibelinya. Umpamanya, mungkin seorang ibu rumah tangga dalam membeli sabun deterjen memilih merk tertentu bukan karena deterjen tersebut dapat mencuci tetapi karena deterjen tersebut dapat mencuci tetapi karena deterjen tersebut ditempatkan dalam sebuah gelas, yang dapat menambah koleksi gelasnya setelah sabunnya habis.

Perlu disadari bahwa tidak selamanya konsumen mau dan mampu mengungkapkan motif pembelian suatu produk. Contohnya, jika kita menanyakan kepada seorang wanita mengapa membeli lipstik merk terkenal dan (biasanya) mahal. Biasanya dia akan menjawab "agar bibir saya tidak kelihatan pucat". Sangat jarang dia secara terbuka menjawab "agar lebih kelihatan sexy" atau "agar saya kelihatan elit". Motif yang demikian itu disebut sebagai latent motif. Sedangkan motif yang secara terbuka diungkapkan oleh konsumen dikenal sebagai manifes motif. Dengan mengetahui apa yang diinginkan oleh konsumen atas suatu produk, akan memudahkan perusahaan dalam mengkomunikasikan atau mengkampanyekan produk tersebut kepada target konsumennya.

Langkah berikutnya adalah mencari tahu bagaimana proses pengambilan keputusan dalam membeli suatu produk. Proses ini biasanya didahului oleh munculnya kebutuhan. Jika kebutuhan dirasakan oleh konsumen untuk segera dipenuhi, maka mereka akan melanjutkan pada proses pencarian informasi, baik secara internal maupun secara eksternal. Dari pencaran informasi tersebut akan muncul criteria evaluasi yang akan dipakai mengevaluasi alternatif produk yang diperkirakan dapat memenuhi kebutuhan tersebut. Proses berikutnya adalah evaluasi dan pemilihan alternatif. Pada proses ini konsumen mengevaluasi karakteristik masingmasing alternatif produk dan memilih salah satu produk yang dianggap paling baik untuk memenuhi kebutuhannya. Setelah itu konsumen akan 
melakukan pemilihan toko dan melakukan pembelian. Proses yang terakhir adalah evaluasi pasca pembelian. Namun demikian, tidak semua pembelian yang dilakukan oleh konsumen akan melalui tahapan pengambilan keputusan yang seperti di atas. Hal ini sangat tergantung pada seberapa jauh tingkat keterlibatan konsumen tersebut dalam pengambilan keputusan.

Jika dilihat pada tingkat keterlibatan konsumen, maka pengambilan keputusan dapat diklasifikasikan menjadi tiga yaitu pengambilan keputusan rutin (habitual), terbatas (limited), dan luas (extended). Dalam pengambilan keputusan yang bersifat kebiasaan/rutin maka ketika muncul kebutuhan, konsumen mencari informasi secara internal dan terbatas untuk kemudian langsung mengadakan pembelian. Jika pada saat pencarian informasi tersebut konsumen hanya mempertimbangkan satu merk saja, maka tipe keputusannya adalah brand loyalty atau konsumen mempertimbangkan beberapa merk maka tipe keputusannya diklasifikasikan sebagai repeat purchases. Jadi untuk model keputusan yang pertama ini, apakah brand loyalty atau repeat purchases, sangat tergantung pada kepuasan atas pembelian sebelumnya dan keadaan pada saat melakukan pembelian, terutama kegiatan pemasaran perusahaan seperti diskn, hadiah dan lainlain.

Selanjutnya, dalam pengambilan keputusan terbatas (limited), konsumen melakukan semua tahap meskipun secara simple. Sedangkan untuk pengambilan keputusan yang luas (extended), konsumen baru pertama kali melakukan pembelian, atau konsumen tidak menghadapi risiko tidak berfungsinya produk yang dipilih. Sehingga konsumen melakukan pencarian informasi yang sangat lengkap, mengevaluasi dan menyeleksi alternatif produk secara hati-hati, dan memilih toko/outlet yang memberikan jaminan atas produk yang akan dibelinya.

Dengan mengetahui tipe pengambilan keputusan konsumen dalam membeli produk yang ditawarkan, perusahaan dapat memprediksi faktor yang mempengaruhi konsumen dalam memutuskan pembelian, memilih cara pelayanan penjualan yang tepat, dan menentukan saluran distribusi yang akan dipergunakan.

Langkah berikutnya adalah membangun citra yang baik dalam benak target konsumen, baik citra merk atau citra perusahaan. Untuk dapat membangun citra merk/perusahaan yang baik ini, perlu memperhatikan proses informasi yang membentuk persepsi konsumen tentang produk perusahaan. Terbentuknya persepsi tersebut dimulai oleh adanya rangsangan yang dikeluarkan oleh perusahaan, baik berupa iklan, penampilan produk, ataupun packagingnya. Jika rangsangan tersebut dapat menarik perhatian target konsumen, maka mereka akan memproses lebih lanjut dengan melakukan interpretasi atas rangsangan yang diterima. Persepsi 
konsumen akan baik/positif, jika rangsangan tersebut mempunyai arti yang baik, dan sebaliknya. Kemudian rangsangan tersebut dapat bertahan lama dalam benak konsumen sangat tergantung pada kesan mereka atas rangsangan itu sendiri dan frekuensi perusahaan dalam memaparkan rangsangan/informasi tersebut kepada konsumen.

Konsumen yang sudah mempunyai persepsi yang sudah baik tersebut masih harus dimotivasi untuk mencoba menggunakan produk perusahaan untuk memunculkan pengalaman konsumsi secara riil, apakah dengan memberikan produk sample, pembelian dengan diskon, atau mencoba menggunakan pada saat perusahaan melakukan promosi penjualan. Jika setelah mencoba produk tersebut, konsumen mempunyai pengalaman yang positif/puas, maka persepsi konsumen terhadap produk perusahaan akan semakin baik.

Namun demikian terciptanya persepsi terhadap produk/merk tidaklah semata-mata berasal dari pengalaman langsung konsumen. Persepsi tersebut bisa muncul sebagai akibat dari adanya komunikasi dengan orang-orang di sekitarnya. Dengan kata lain, informasi atau pengalaman orang lain dapat membentuk persepsi konsumen terhadap suatu produk/merk. Apakah persepsi yang muncul adalah persepsi yang positif atau negatif sangat tergantung pada informasi yang dia terima. Jika seseorang mempunyai pengalaman yang memuaskan dalam mengkonsumsi suatu produk/merk tertentu dia akan memberikan informasi yang positif tentang produk/merk tersebut kepada orang lain (positive word to mouth). Sebaliknya, orang tersebut akan memberikan informasi yang negatif jika mereka tidak puas terhadap suatu produk/merk (negative word of mouth). Positive word of mouth dapat membentuk persepsi yang baik, sedangkan negative word of mouth akan membentuk persepsi yang kurang baik terhadap produk/merk yang diinformasikan. Dalam beberapa hal, word of mouth (informasi getok tular) lebih dipercaya oleh konsumen daripada informasi yang disediakan oleh produsen. Sehingga sangat dimungkinkan konsumen yang sudah mempunyai persepsi yang baik akan menjadi netral atau bahkan menjadi tidak baik setelah mendapat informasi negatif dari lingkungannya tentang penampilan riil dari suatu produk/merk.

Dari uraian di atas, nampak bahwa usaha promosi yang dilakukan perusahaan tidak hanya untuk menginformasikan tentang keberadaan produk perusahaan di pasar, melainkan untuk membangun citra positif sehingga produk perusahaan tersebut dapat menjadi alternatif pemenuhan kebutuhannya. Hal ini sangat penting bagi perusahaan, karena persepsi konsumen terhadap produk adalah lebih penting daripada kenyataan yang melekat pada produk itu sendiri. Mengingat, dalam beberapa hal, konsumen lebih mempertimbangkan merk daripada produknya pada saat melakukan pembelian dan mereka memilih merk tertentu karena merk tersebut 
mempunyai persepsi yang baik dalam benaknya. Umpamanya Sony untuk produk audio dan audio visual, National untuk consumer electronic.

Langkah terakhir untuk dapat memuaskan kebutuhan konsumen adalah adanya kesadaran bagi semua unit yang ada dalam perusahaan akan pentingnya kepuasan konsumen bagi kelangsungan hidup perusahaan. Kesadaran semacam ini harus diimplementasikan dengan tindakan nyata bahwa semua unit dalam perusahaan merupakan pemasar. Dengan kata lain tugas pemasaran (memuaskan konsumen) tidak hanya dilakukan oleh bagian pemasaran saja, tetapi menjadi tanggung jawab semua unit yang ada. Jika pemuasan konsumen tidak menjadi misi yang memotivasi setiap bagian organisasi, maka pembentukan citra tidak akan maksimal. Umpama, konsumen yang sudah tahu bahwa kualitas suatu merk/produk tersebut bisa menjadi kurang baik, karena kekurang-ramahan pelayanan pada saat transaksi dilakukan. Atau kepuasan konsumen terhadap merk/produk dan pelayanan penjualan bisa menjadi pudar jika yang bersangkutan mengalami kekecewaan dalam pelayanan pasca pembelian.

Namun demikian, bukanlah berarti bahwa jika semua unit dalam perusahaan sudah menjalankan fungsinya dapat menghilangkan munculnya kekecewaan (complain) konsumen. Kekecewaan konsumen sangat sulit untuk dihindari perusahaan. Hal ini karena keberagaman keinginan dan selera konsumen yang tidak mungkin dapat dipenuhi seluruhnya oleh perusahaan. Oleh karena itu, untuk meminimalkan penurunan citra yang diakibatkan dari kekecewaan konsumen terhadap penampilan produk atau pelayanan yang diterima, maka perusahaan perlu menangani komplain konsumen (consumer complain secara serius dan hati-hati. Keseriusan dan kehati-hatian ini perlu dilakukan untuk mengurangi penyebaran informasi negatif negative word of mouth communications) yang pada akhirnya dapat menurunkan citra merk/produk bahkan citra perusahaan secara keseluruhan. Sehingga tidak mengherankan jika banyak perusahaan di negara-negara maju yang menyediakan consumer hot lines yaitu nomor telpon bebas pulsa sebagai sarana untuk menerima komplain atau kekecewaan konsumen. Filosofi yang mendasari kebijakan seperti ini adalah memfasilitasi konsumen untuk menceritakan kekecewaannya langsung kepada perusahaan, dan tidak menyebarkan informasi negatif kepada orang lain. Karena pada dasarnya penanganan komplain konsumen seperti ini hanya berfungsi mengurangi penyebaran informasi negatif, tetapi juga bermanfaat sebagai umpan balik bagi perusahaan untuk pengembangan produk dan pelayanannya.

Konsep pemuasan konsumen terpadu seperti di atas bisa terrealisir, jika dalam perusahaan menjadikan pemasaran sebagai konsep bisnis strategic yang memberikan kepuasan yang berkelanjutan bukan sesaat, tidak hanya bagi investor/pemilik dan konsumen tetapi juga memberikan 
kepuasan yang berkelanjutan juga bagi para karyawannya. Hal ini berangkat dari kenyataan bahwa sangatlah sulit bagi perusahaan mendisiplinkan karyawannya untuk memberikan pelayanan yang memuaskan kepada para pelanggan, jika pada saat yang bersamaan mereka (para karyawan) merasa tidak puas atas apa yang mereka terima dari perusahaan. Atau sebaliknya, tidak akan ada artinya bagi perusahaan yang mampu memuaskan para karyawan dan investornya, jika mereka gagal dalam memuaskan para pelanggannya, yang notabene nya merupakan sumber penghasilan bagi perusahaan.

\section{KESIMPULAN}

Mengingat sebagian besar para pelaku bisnis di Indonesia saat ini berperasi di industri yang tingkat persaingan dan perubahannya cukup tinggi, maka paling tidak marketing philosophy yang mendasari produknya adalah konsep pemasaran. Perusahaan yang menggunakan konsep ini dalam falsafah bisnisnya berasumsi bahwa perkembangan dan kontinjuitas perusahaannya sangat tergantung seberapa jauh mereka dapat memuaskan para konsumennya.

Dalam rangka terciptanya kepuasan konsumen tersebut, perusahaan akan berusaha untuk mengetahui: (1) minat yang mendasari konsumen membeli produk mereka; (2) proses pengambilan keputusan pembelian produk tersebut; dan (3) penilaian (persepsi) para konsumen terhadap produk perusahaan jika dibandingkan dengan produk pesaing. Dengan memahami ketiga hal tersebut akan memungkinkan perusahaan untuk dapat memilih metode dan media komunikasi yang tepat dan sesuai dengan pasar sasarannya dan mempunyai pedoman untuk menetapkan strategi pelayanan, saluran distribusi, bersaing dan pengembangan produk di masa yang akan datang.

Namun demikian perlu disadari bahwa kepuasan konsumen tidak semata-mata berasal dari baiknya kualitas produk, tetapi juga dipengaruhi oleh faktor lain seperti pelayanan pada saat dan sesudah pembelian, cara pembayaran, tersedianya spare part dan lain-lain. Oleh karena itu, untuk memaksimalkan kepuasan konsumen dan terciptanya citra merk/produk perusahaan yang baik, maka memuaskan konsumen tidak lagi menjadi tanggung jawab seluruh bagian yang ada dalam perusahaan. Agar pemuasan konsumen dapat dilakukan secara terpadu, maka perusahaan sebaiknya menggunakan pemasaran sebagai konsep bisnis strategic yang memberikan kepuasan yang berkelanjutan, bukan sesaat, tidak hanya bagi investor/pemilik dan konsumen tetapi juga memberikan kepuasan yang berkelanjutan juga bagi para karyawannya. Dalam konsep ini perusahaan berusaha untuk memuaskan semua stakeholder nya. 
DAFTAR PUSTAKA

Kotler, Philip (1994), "Marketing Management: Analysis, Planning, Implementation, and Contrl", Englewood Cliffs, New Jersey, Prentice Hall Inc., Edisi Delapan.

Hawkin, D.I; R.J. Best, \& K.A. Coney (1992), "Consumer Behavior: Implication for Marketing Strategy", Texas, Business Publication Inc., Edisi Lima.

Engel, J.F; R.D. Blackwell, \& P.W. Miniard (1993), Consumer Behavior, Florida, The Dryden Press, Edisi Tujuh.

Assael, Henry (1992), Consumer Behavior \& Marketing Strategy, Boston, Massachussetts, PWS-KENT Publishing Company, Edisi Empat. 